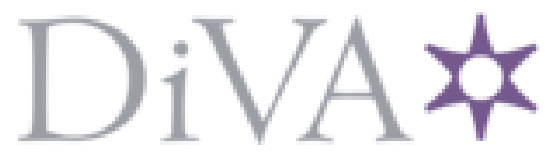

http://www.diva-portal.org

\title{
Postprint
}

This is the accepted version of a paper published in Journal of Place Management and Development. This paper has been peer-reviewed but does not include the final publisher proof-corrections or journal pagination.

Citation for the original published paper (version of record):

Björner, E. (2013)

International positioning through online city branding: the case of Chengdu.

Journal of Place Management and Development, 6(3): 203-226

https://doi.org/10.1108/JPMD-03-2013-0006

Access to the published version may require subscription.

N.B. When citing this work, cite the original published paper.

Permanent link to this version:

http://urn.kb.se/resolve?urn=urn:nbn:se:su:diva-98795 


\section{International positioning through online city branding: the case of Chengdu}

\author{
Emma Björner \\ Stockholm University School of Business, Stockholm, Sweden
}

\begin{abstract}
Purpose - The aim of the present study is to add to the existing research on online city branding by studying how metropolitan cities are internationally positioned using the internet and online branding. The focus is on objectives and strategies, method and expression (including five illustrations), and challenges in online city branding.

Design/methodology/approach - The article relies on a single-case study approach, using the Chinese city of Chengdu as a case and illustration. Methods used are interviews, observations and documentation (including online material).

Findings - The study illustrates how Chengdu uses online city branding in its international positioning. Chengdu's online branding is influenced by certain imagery, as well as challenges. Collaboration and endorsement crystalize as central elements in Chengdu's online city branding.

Research limitations/implications - This article and study can be seen as an important element in broadening the understanding for online city branding to international audiences.

Practical implications - The study offers insights to practitioners on how online city branding is carried out in a Chinese context and in the city of Chengdu.

Originality/value - The study can be regarded as an important contribution to an area of practice and research which still is fairly new and unexplored, and an area that hitherto has not been well covered in the international literature.
\end{abstract}

Keywords China, Case study, Chengdu, City branding, International positioning, Online branding

Paper type Case study

\section{Introduction}

In an increasingly global and competitive world, international positioning through online branding has become a necessity for cities that wish to compete in the global arena. Having an official web presence is today seen as an essential city branding tool, and cities in the contemporary setting are increasingly using social media in their branding efforts (Paganoni, 2012). In the corporate world and society at large, social media has become a necessary element, and it has been said that if you do not

The author would like to extend her appreciation to the National Academy of Economic Strategy (NAES) at the Chinese Academy of Social Sciences (CASS), and especially Dr Liu Yanping for his and his organization's support during her stay in China in June and July 2012. She would also like to extend her appreciation to the Forum for Asian Studies at Stockholm University, for enabling the data collection in China referred to and included in this article. Moreover, she would like to show her gratitude to her supervisors, Prof. Per Olof Berg, Prof. Ali Yakhlef and Prof. Fan Xiucheng, and to her colleagues at Stockholm University School of Business (SUSB), for supporting her in the research. Last but certainly not least she would like to extend her gratefulness to the interviewees that have shared their thoughts with her on city branding in China.
Online city branding

Received 18 March 2013 Revised 28 June 2013 Accepted 5 July 2013

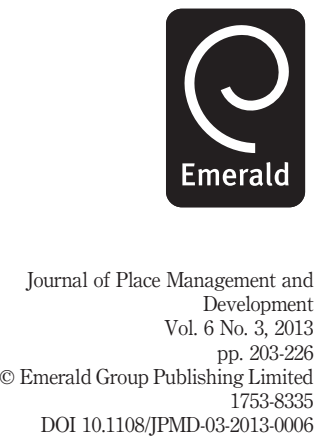


JPMD

6,3

204 participate in Facebook, YouTube and other social media, you are no longer part of cyberspace (Kaplan and Haenlein, 2010). For cities, use of the internet and online branding can be seen as a response to the inter-urban competition among cities all over the world, and the encouragement of cities to become networked in a global, digitized arena (Sassen, 2004).

An increasing research body is being formed around the topic of online city branding. Related studies can also be found in nearby areas of research, e.g. in corporate branding and tourism marketing. It has been claimed that online branding can assist in providing useful information, raise awareness, encourage brand remembrance, attract users, engage users and create participation (Hays et al., 2012; Rowley, 2004a). Using a multi-channel strategy and combining offline and online branding has been emphasized as important (Rowley, 2004b; Simmons, 2006). The expression that online branding takes (e.g. through its brand design, brand behaviour, brand communication) has also been put forth as central (Florek et al., 2006). The move from branding in the era of Web 1.0 to branding in the Web 2.0 context, and the increased interactivity, dialogue and distributed structure this brings, has also partially been discussed in the literature (Christodoulides, 2009; Florek, 2011; Fouts, 2010).

Online city branding is however still an area of practice and research that is fairly new and unexplored. Gaps remain, requiring further elaboration. Hitherto, the majority of studies have been focused on either web sites or social media, not both, and consequently lack an all-encompassing perspective on online city branding. There are also limited examples in the literature explaining how cities combine online and offline branding efforts. Furthermore, present studies mention, but glance over, potential challenges in online city branding.

The aim of this article is to address these identified gaps, and add to existing research on online city branding by studying how metropolitan cities are branded using the internet and online branding. The study relies on a case study approach, focusing on the Chinese city of Chengdu as a single-case study and illustration. The methods used are interviews, observations and documentation. The study shed light on how Chengdu has been branded online, to international audiences. The paper focuses on Chengdu's objectives and strategy, method and expression (including five illustrations), and challenges in online city branding.

\section{Literature review \\ City branding}

Cities today increasingly compete with each other in order to attract investors, tourists, residents, and workforce (Kavaratzis, 2005; Zenker, 2009; Zenker and Martin, 2011). As a response to this competition and to stay competitive and relevant on the global market of cities - cities all over the world engage in marketing and branding efforts (Hospers, 2010). Increasing effort is also put into establishing the city as a brand (Zenker and Martin, 2011). It is claimed that city branding, among other things, can increase inward investment and tourism, create competitive advantage and boost city image (Balakrishnan, 2009; Kavaratzis, 2004).

City branding can moreover be used as a strategic approach to provide cities with a source of economic value as well as political and cultural significance (Balakrishnan, 2009; Kavaratzis, 2004). Kotler and Gertner (2002) and Rainisto (2003) emphasize the need for strategic tools in order for cities to be able to attract tourists, factories, 
companies and talented people. City branding can also be seen as an instrument to make a city's competitive advantage known, and to promote the history of the city, the quality of the place, its lifestyle and culture (Zhang and Zhao, 2009).

There is limited clarity and agreement about terminology and definitions in the city branding literature (Anholt, 2005), and there appears to be more agreement over what city branding and place branding is not, than over what it is. Yet, there is an increasing body of research and practice related to city branding (Hanna and Rowley, 2011). City branding has been defined as a "continuous process interlinked with all marketing efforts and with the whole planning exercise" (Kavaratzis, 2007, p. 704). City branding has also been described as "the purposeful symbolic embodiment of all information connected to a city in order to create associations around it" (Lucarelli and Berg, 2011, p. 21). The present study ascribes to these two definitions.

City branding stems from tourism marketing and destination branding (Hanna and Rowley, 2011) and from branding and corporate branding (Anholt, 2005; Dinnie, 2011; Kavaratzis, 2004). In the literature, parallels have been drawn between city branding and product-, service-, and corporate branding. It has been claimed that city branding is profoundly different from product and service branding, especially as city branding involves many more complexities, arising from the number of organisations influencing the city branding, the diversity of the stakeholders, and the limited control that brand managers have over the city branding process and the different target groups (Kavaratzis, 2009).

Between corporate branding and city branding there are more similarities, for example Anholt (2002) points to the relevance of the "metaphor of place as corporate brand". Similarities between corporate brands and city brands are; that they address numerous stakeholder groups, have multidisciplinary roots, need to consider social responsibility, are highly complex and intangible, and deal with multiple identities (Kavaratzis, 2004). There are also differences between corporate branding and city branding. The complexities involved in city branding are greater than in corporate branding, and the difficulties are more acute. It is for example harder for a city to adopt and project a single clear identity, ethos and image, and maybe not even desired (Kavaratzis, 2009), implying that the goals of the company and the city may be different. Furthermore, cities do not compete in the same way that companies compete, with profit maximisation as the most important objective. Cities instead compete for residents, tourists, funding, events, investments, etc. (Lever and Turok, 1999). In this study city branding is viewed as different from product-, service-, and corporate branding. Yet, it is in the frame of this article, regarded worthwhile to draw inspiration from these areas in order to understand online city branding.

\section{Online branding in related research fields}

In product and service marketing, the internet has been seen as revolutionizing marketing and communication efforts in various ways. The introduction of new online marketing channels has enabled individual promotions to customers, improved services, and been regarded as a way to improve traditional marketing efforts. It has also been claimed that online branding/marketing can be more effective since digital technologies enable individual attention, better campaign management, and improved product and marketing design (Urban, 2004). Rowley (2004a, p. 137) has proposed some possible objectives of online branding, including raising awareness of online and

\section{Online city branding}

205 
JPMD

6,3

206

offline services; encouraging a higher level of use; enhancing effectiveness of communication between users and the organization; encourage more frequent visits to the web site; encourage users to use a wider range of online services; get people to remember the brand mark; and change people's attitude to the organization.

Research related to tourism marketing and destination branding suggests that the internet is an effective marketing tool in tourism (Law et al., 2010). The internet can be seen as reshaping "the way tourism-related information is distributed and the way people plan for and consume travel” (Xiang and Gretzel, 2010, p. 179). The internet has moreover become the number one source of information when travellers choose destinations (Gertner et al., 2007). The internet can also be regarded as an efficient channel for selling, for direct distribution of goods and services, and as a support channel for customer feedback (Da Silva and Syed Alwi, 2008).

Social media is also playing an increasingly important role in marketing and branding, for example, as an information source for travel (Xiang and Gretzel, 2010). Social media has been defined as "activities, practices, and behaviours among communities of people who gather online to share information, knowledge, and opinions using conversational media” (Hays et al., 2012, p. 2). Conversational media is moreover described as applications that are web-based and that enable creation and transmission of content such as pictures, audio, words and video. In Hays et al.'s (2012) view, social media is gaining importance as an element of destination marketing organizations' (DMOs) marketing strategies - especially at a moment in time when the public sector is cutting funding, and social media can enable DMOs to reach global audiences with limited resources. In Kaplan and Haenlein's (2010, p. 67) view, social media enables companies to "engage in timely and direct end-consumer contact at relatively low cost and higher levels of efficiency than can be achieved with more traditional communication tools". Hays et al. (2012) have proposed a cycle for successful social media marketing (Figure 1).

Florek et al. (2006) concluded in their study of 16 New Zealand city council web sites that the expression of place brand identity and image is represented in three dimensions:

Figure 1.

Cycle of key steps for successful social media marketing

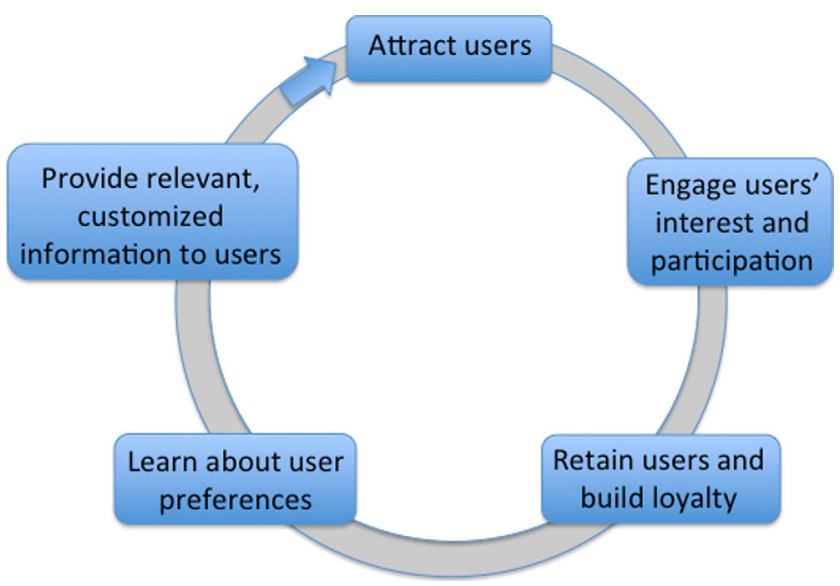

Source: Hays et al. (2012) 
(1) Brand design. The actual design of the web site, including tangibilised attitudes of the city (e.g. slogan, logo, video, webcam, picture gallery, maps).

(2) Brand behaviour. The actual activities and types of information to be found on the web site (e.g. news, public notices, projects, plans, policies, reports, events, calendar, contact, community board members, sister cities).

(3) Brand communication. Attitudes expressing values, opinions and intent, e.g. the way city councils relate to and interact with their publics (e.g. general information/overview of the city, customized information for target audiences, feedback tools, links to related web sites).

\section{Online and offline branding}

Online branding is seen by many researchers as inseparable from offline branding. Rowley (2004a, p. 136) discusses different stages of what businesses can do to build a brand online, and put emphasis on the importance for managers to identify "elements of consistency and elements of differentiation between offline and online modes". Rowley has also claimed that values embraced and communicated offline should moreover be echoed in online channels. When it comes to the development of an internet marketing strategy, Chaffey et al. (2009), have maintained that the integration between internet channels and traditional channels is a key element. The same scholars have emphasized the importance of alignment between the internet marketing strategy and the overall business strategy, putting focus on the need for clear objectives for the development of a brand.

Dobers and Hallin (2009) have similarly suggested that there is a need to develop a multi-channel strategy for branding communications, including internet and digital marketing, in addition to more traditional channels. Go and Govers (2010) have maintained that it is important to reflect the same brand values and brand identity online and offline. These brand values should moreover create a sense of consistency, authenticity, purpose, and sensory appeal. Many organisations see the need to integrate marketing communications offline and online, which makes it hard to separate the two, both practically and theoretically (Rowley, 2004b). Yet, there are limited studies showing how cities combine online and offline branding efforts.

\section{Changes and challenges in online branding}

The use of the internet in branding and marketing has changed over time. In the early days of the internet, brand managers often replicated offline marketing efforts on the internet, with the result that web sites were very static, and "brochureware". In line with the shift from Web 1.0 to Web 2.0 (Figure 2), the factors important in Web 1.0 (e.g. site appearance, navigation and physical delivery) have developed to include hygiene (i.e. need to be there), and are complemented by a number of additional factors, including blogs, viewer created ads, video-sharing sites, web-based communities, hosted services, web applications, social-networking sites, etc. (Christodoulides, 2009; Florek, 2011). Kaplan and Haenlein (2010, p. 61) discuss social media, stating that it is "a group of internet-based applications that build on the ideological and technological foundations of Web 2.0" allowing for formation and exchange of user generated content.

Florek (2011) has explained that Web 2.0 is often associated with applications that facilitate interactive information sharing, interoperability, user-centred design, and collaboration on the internet. The move to Web 2.0 implies new factors that to a large degree are outside the organization's control (Christodoulides, 2009). The internet and 
JPMD

6,3

208

Figure 2.

Web 2.0 branding

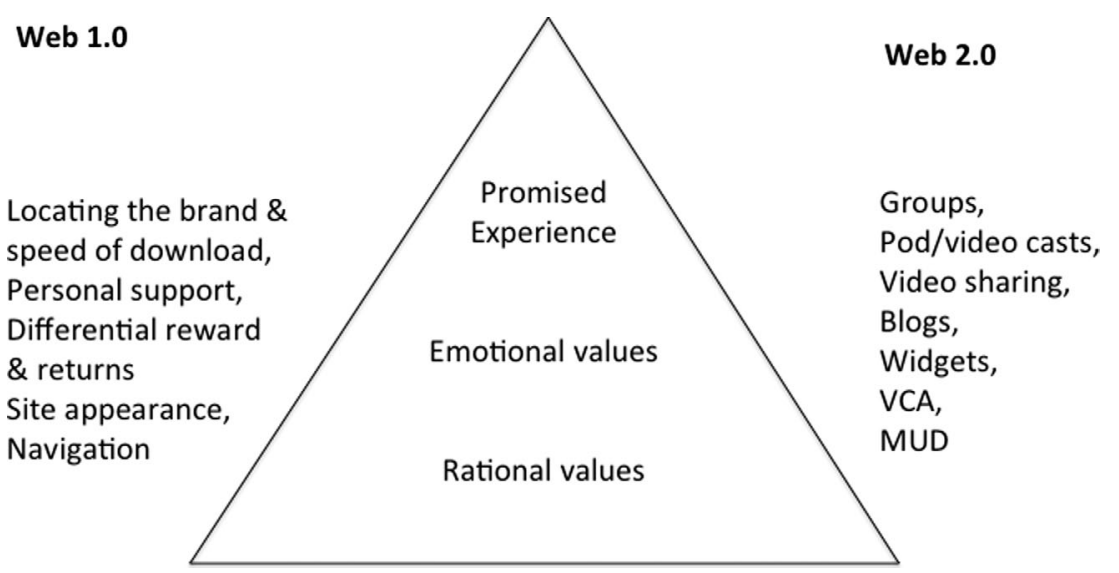

Source: Christodoulides (2009, p. 143), copyright (C) 2009 by SAGE, reprinted by permission of SAGE

Web 2.0 have created a new form of dialogic citizenship (Paganoni, 2012), inviting users to engage in direct and strong participation (Florek, 2011). Thus, consumers can no longer be regarded as passive recipients of brand value, but should be seen as co-creators of meaning (Christodoulides, 2009).

In a review of the literature on online branding, Simmons (2006) claims that the internet has made branding a more complex and dynamic challenge. Also Rowley (2004a) maintains that branding in an online environment poses a number of challenges that are important to explore in order to understand some of the potential impacts of online channels for branding strategy. Few scholars however elaborate on the challenges related to online city branding. Yan (2011) discusses why organizations engage in online branding, and some of the challenges associated with online branding, concluding that brands cannot be controlled centrally in a top-down manner. In Yan's view, the "them" and "us" becomes obsolete in online branding. Instead, companies need to collaborate with consumers for everyday marketing purposes. If sticking to a top-down approach in online branding, the organization will come across as being separate and non-transparent. Abandoning the top-down process on the other hand, implies accepting inputs from audiences to drive strategies (Yan, 2011). Christodoulides (2009, p. 142) similarly states that command and control branding cannot be tolerated online. Instead, "post-internet branding is about facilitating a conversation around the brand".

A result of the increasing use of the internet in city branding is that brand managers need to implement new tools to build and communicate their brands (Florek, 2011). In line with increased participation, co-creation and dialogue (that the internet and Web 2.0 is driving) Fouts (2010), detects a change from a hierarchical structure to a distributed structure. Along with the increase in popularity of social media, Web 2.0 and the internet, the authority of marketers and institutions declines (Thevenot, 2007). Leadership, as well as trust, still however remain key issues in electronic marketing, Palmer (2004) maintains. He furthermore states that strong and effective leadership is crucial in order to achieve the objectives of a group, and central when the aim is to reconcile the interests of multiple stakeholders. 
Online city branding

Various communication channels, of which internet and digital marketing has been emphasized as crucial, are used when branding cities (Ulaga et al., 2002). It has been maintained that digital marketing and online activities related to places and cities can result in a positive image for cities (Trueman et al., 2012). It has also been stated that the internet today has become an important tool when local governments try to develop a city's image (Dobers and Hallin, 2009). Having an official web presence is moreover increasingly regarded as a vital branding tool for local governments. Today's digital cities are also engaging more and more in social networking media (Paganoni, 2012). This can be seen as a response to inter-urban competition and the encouragement of cities to become networked in a global, digitized arena (Sassen, 2004).

Studies in the field of online city branding published in international journals, in English, has been focused on online city branding more generally and the impacts from Web 2.0 (Florek, 2011), e-branding of places and the online marketing of web sites in Dubai (Go and Govers, 2010), online brand personalities studying a selection of African countries (Opoku and Hinson, 2006), city branding and social inclusion, focusing on city council web sites (Paganoni, 2012), the use of internet in building the brand of Stockholm (Dobers and Hallin, 2009), city council web sites as a means of place brand identity communication (Florek et al., 2006), the role of social media in online travel information search (Xiang and Gretzel, 2010), social media and immersive worlds (Fouts, 2010), and the internet challenge for DMOs (Palmer, 2004).

Some scholars have focused on online branding in relation to destination marketing and DMOs (Hays et al., 2012; Xiang and Gretzel, 2010; Palmer, 2004). Others have focused on online branding and online marketing in relation to organizations - not in connection with cities or places (Yan, 2011; Christodoulides, 2009; Rowley, 2004a; Simmons, 2006; Varadarajan and Yadav, 2009). Yet, limited studies have connected online branding and city branding. Furthermore, some researchers have focused their studies on web sites (Rowley, 2004a; Opoku and Hinson, 2006; Choi et al., 2007; Dobers and Hallin, 2009; Florek et al., 2006; Go and Govers, 2010), whereas others have addressed social media (Hays et al., 2012; Xiang and Gretzel, 2010; Fouts, 2010). Few scholars have however focused on both web sites and social media. The focus on either web sites or social media can be critiqued for lacking an all-encompassing perspective on how cities are branded online.

\section{Summing up and setting the frame}

Buhalis and Spada (2000) maintained that research on the internet as an image formation agent still was at an infancy stage. Rowley (2004a) claimed that the role of brands and branding in the digitized and globalized economy was attracting considerable attention. Florek et al. (2006) called for further research on the integration of web sites with other place identity branding tools. Dobers and Hallin (2009) stated that cities and local governments still represented a sector where online branding had played a limited role, and that there in the city branding literature still were inadequate studies that had dealt with how cities use internet and digital marketing in their city branding efforts. Hays et al. (2012), claimed that use of social media among top DMOs still was largely experimental and that strategies varied greatly. The same scholars predicted that tourism organisations that fail in adopting social media would come to lack competitive advantage.

In the present literature review the author of this paper has, in addition to giving a brief overview of previous research, addressed three main problems relating to the

\section{Online city branding}

209 
JPMD

6,3

literature on online city branding. First, the majority of studies have studied either web sites or social media, not both, and consequently lack an all-encompassing perspective on online city branding. Second, there are limited examples in the literature showing how cities combine online and offline branding efforts. Third, the literature mentions but glances over potential challenges in online city branding.

The starting point for this study is previous studies, concepts and frameworks, with a certain focus on four frames of reference already mentioned in this review, namely:

(1) Rowley's (2004a) proposed objectives in online branding.

(2) Hays et al.'s (2012) proposed cycle for successful social media marketing.

(3) Florek et al.'s (2006) three dimensions of place brand identity and image.

(4) Christodoulides (2009) figure depicting Web 1.0 and Web 2.0.

These concepts and framework can moreover be connected to three main themes that this study put focus on, namely:

(1) Objectives and strategies. Raise awareness, encourage use, brand remembrance, etc. (Rowley, 2004a); attract users, engage users interest and participation, learn about user preferences, provide relevant information (Hays et al., 2012).

(2) Method and expression. Multi-channel strategy (Rowley, 2004b); combining traditional and online branding (Rowley, 2004a; Simmons, 2006); brand design, brand behaviour, and brand communication (Florek et al., 2006).

(3) Challenges. Web 1.0 and Web 2.0 branding (Christodoulides, 2009); interactivity (Florek, 2011); move from hierarchical to distributed structure (Fouts, 2010).

This article and study aims to add to existing research on online city branding by studying how metropolitan cities are internationally positioned and strategically branded using the internet and online branding. The main focus is on "Objectives and strategies", "Method and expression" and "Challenges in online city branding". The focus in this study is on the producer perspective and thus on how the city brand management is carried out. The focus is primarily on the communication and branding aimed at international, overseas audiences. The Chinese city of Chengdu is used as a case study, illustrating how Chengdu uses online branding in its international positioning. Since online branding can and should not be separated from offline branding (Rowley, 2004b), the focus is on both online and offline city branding, but with an emphasis on online city branding. The starting point is also a focus on web sites and social media, and Web 1.0 as well as Web 2.0.

\section{Research method}

In the marketing field, theory-testing methodologies such as surveys and experiments have, for a long time, been the dominant methodologies. Today, qualitative methodologies such as case studies and field interviews are however regarded as essential to developing theory in marketing (Alam, 2005). In terms of methods used in China, the predominant technique has been, and to a large degree still is, belonging to the quantitative paradigm (Polsa, 2013). In Asia, qualitative methods are still underrepresented in marketing research (Eckhardt and Dholakia, 2013). The present study adopts an abductive approach, and is as such a combination of inductive and deductive research. The aim has been to have a pre-understanding and theoretical founding, yet leaving room for serendipity and 
new, unexpected discoveries (Dubois and Gadde, 2002). The approach taken has been to partly let the topic of inquiry, and the concepts and theories employed to understand it, evolve in the course of conducting the research (Heimer and Thøgersen, 2011).

\section{Single case study}

A case study research strategy appeared appropriate in this study due to its advantage when the aim is related to "how" or "why" questions about a contemporary phenomenon and/or set of events that the researcher has little control of Yin (2003). The main questions posed in this study were of the "how" and "why" character, with the main aim to study how large metropolitan cities are branded online towards international audiences. Using a case study approach moreover seemed suitable due to its ability in catching the complexity of a single case, enabling an understanding for activity within important circumstances (Stake, 1995). Strengths of the case study research approach include its ability to deal with multiple sources of evidence, including interviews, documents, observations, artefacts, etc. (Yin, 2003). Moreover, a successful case study can offer the reader a three-dimensional picture as well as illustrate relations and patterns of power, in a certain context and in a certain situation (Bell, 1999).

In the present article and study the focus is on a single-case, namely the Chinese city of Chengdu and its online city branding to international audiences. Chengdu is interesting as a case and illustration partly because it is one of the forerunners in the Chinese setting when it comes to city branding. Chengdu is involved in online city branding, is aiming to attract investors and tourists, improve its image, and become a global player. The city is using a multi-channel strategy (i.e. uses different communication and marketing channels in its branding efforts), and combines offline and online branding as well as web sites and social media. To date, there are limited studies published in international journals illustrating online city branding in Chinese cities. All in all, China is a context in which city branding has been researched to only a limited degree (Wai, 2006), yet an environment where city branding increasingly is practiced and researched.

\section{Chengdu and Chinese cities}

Chengdu and Chinese mega-cities are interesting to study since they are eager to become international cities, compete with other cities (for investments, tourists, residents, etc.), and are increasingly branded in the global arena. China and Chinese cities are moreover taking on powerful positions in the world, and are integrating with the world economy (Wang and Zheng, 2010). Additional reasons for the interest in studying a Chinese city like Chengdu, are related to the claims made that the Chinese context has dimensions different from the Western context, and that China cannot be understood through a Western prism but should be studied on its own terms (Jacques, 2009). Chinese cities display characteristics that set them apart from their Western counterparts, e.g. governance and control. In China, strong leadership characterizes the urban government structure, and city branding is often carried out in a relatively controlled and governed manner (Wu, 2000, 2003; Xu and Yeh, 2005).

\section{Interviews, observations, documentation}

The majority of the data in the present case study was gathered from May to July 2012, in Chengdu, Beijing and Shanghai. The methods were interviews, observations, and documentation.

\section{Online city branding}


JPMD

6,3

212

It has been said that interviewing has become the heart of much fieldwork conducted in China, since it became possible in the late 1970s. It has also been maintained that interviewing can play a vital role in theory building by, e.g. revealing institutional environments (O'Brien, 2011), which can be regarded as suitable in the present study as it largely relates to the producer perspective as well as strategies and work of city brand management organisations. In total, ten interviews were conducted and used in the frame of the present study. The interviews were of semi-structured character, and conducted in China - primarily in Chengdu, but also in Beijing and Shanghai. The interviewees were people engaged in work related to city branding of Chengdu and online city branding. Interviews were conducted with representatives from the information office and the investment office of Chengdu Government, Chengdu Culture and Tourism Group, PR and consultancy firms, the City Channel, Chengdu Academy of Social Sciences, the City Branding Studio at Tsinghua University, and the National Academy of Economic Strategy, at the Chinese Academy of Social Sciences. The interviews lasted for between 30 and 70 minutes. The questions were focused on online branding of Chengdu, branding of Chengdu in general, and international positioning of Chengdu. Depending on the answers, the prepared question guideline was followed relatively closely.

Observational studies have been central in much qualitative research, and often the method chosen when the aim is to understand another culture or sub-culture (Silverman, 2005). Observational evidence is moreover often useful when it comes to providing supplementary information about the topic under study (Yin, 2003). The observations within the frame of the present study include photographs and a work-log with diary notes. The work-log includes approximately 15,000 words, and depicts experiences from the field as well as more informal conversations with people regarding the city of Chengdu, city branding efforts, and online branding in Chengdu. The documentation consists of printed documents, brochures, newspaper clippings as well as other materials given to the author of this paper. It also includes materials gathered online depicting the branding of Chengdu, consisting of general information about Chengdu and its city branding efforts as well as examples of how Chengdu has been branded online towards international audiences.

\section{Analysis}

The analysis phase has been guided by the abductive approach taken in the present study. The analysis of the data has been focused on generating new concepts and development of theoretical models, rather than confirmation of existing theory (Dubois and Gadde, 2002). Nevertheless, a pre-understanding of existing theory related to the area of online city branding was gained before entering the field. As stated by Yin (2003), every case study should have a general analytic strategy, outlining the significance of analyzing what and why. The literature review and the conceptual framework developed in this paper, has assisted greatly in defining and founding the analytic strategy used in the present study.

Three main problems were outlined in the literature review, related to:

(1) a focus on web sites or social media - not both;

(2) limited studies on the challenges in online branding; and

(3) a lack of studies on how cities combine online and offline branding. 
These three issues, in combination with previous research and especially four previous studies (Hays et al., 2012; Florek et al., 2006; Rowley, 2004a; Christodoulides, 2009) were used as the starting point that came to guide the research. The data from the interviews were analysed in a systematic manner involving detailed readings of the raw data to derive concepts and themes (Thomas, 2006), resulting in ideas and concrete details (Neuman, 2007). The analysis of the web-based materials consisted of textual analysis (Silverman, 1993) and the study of communication messages including both textual and visual contents of web sites and social media (Choi et al., 2007). Throughout the analysis the aim has been to address the most significant aspect of the case study, and to take major rival interpretations into consideration (Yin, 2003).

\section{Findings}

In the following presentation of the findings, data from interviews, observations and documentation are presented. The interviewees' "voices" are narrated in parallel with illustrations of online city branding and international positioning. The starting point is based on the findings from the literature review, and the notion that there is a need for a study focus on social media and web sites (incorporating both Web 1.0 and Web 2.0), and on online as well as offline branding. The outcome of the literature review moreover guides the presentation of the findings, and is focused on three main themes, namely "Objectives and strategies", "method and expression", and "Challenges with online city branding". Before that a brief context description of city branding in Chengdu and Chinese cities is supplied. In the second part, focusing on "Method and expression”, five illustrations of Chengdu's online city branding are included.

\section{Context: Chengdu city branding}

The policies from the central government encourage all Chinese cities to "go out and sell themselves", important aims being to attract investments and tourists. internet, digital marketing and social media are used increasingly in the branding of Chengdu and other Chinese cities:

Chinese city governments are putting more and more focus on digital media, and government officials understand that digital media and digital marketing is important, but they are lacking skills in how to use it.

So far, most cities have used traditional media such as TV, magazines and newspapers in their city branding practices, and in some Chinese cities there is still a conservative attitude towards digital and online media, one reason being that it is hard to control.

Most Chinese cities have a similar structure when it comes to city branding, in that it is always managed by the government:

In Chengdu, it is the Information office at the Publicity department that has the holistic, overall responsibility for city branding.

The information office of the Publicity department gives directions regarding city branding, engages in the overall planning and city design, and coordinates branding efforts. Other governmental offices (e.g. focusing on investment, tourism, and culture), institutions, bureaus and private companies are however also involved in the branding of Chengdu.

In the last ten years Chengdu has been branded towards international audiences more and more. Between 2003 and 2008, Chengdu was mainly involved in domestic

\section{Online city branding}

213 
JPMD

6,3

\section{4}

city branding. In 2008, Sichuan province and Chengdu suffered from an earthquake taking the lives of approximately 70,000 people. At that time about 3,000 journalists came to Chengdu. The earthquake and the arrival of journalists became a spark to increase the focus on city branding in Chengdu. As expressed by one of the interviewees:

The earthquake in Sichuan province in 2008 became a trigger and a starting point to rebuild the image of Chengdu.

In 2008, at the time of the earthquake, an international consulting company began to work with Chengdu's Government, and started conducting research internationally about the perception of Chengdu. A respondent explained the purpose of the research:

The research intended to understand perceptions and desires of international people, mainly focusing on people in the US, in Europe and in Asian countries. The purpose of the research was also to improve the image of Chengdu.

\section{Objectives and strategies}

The target set for Chengdu is to be among the third tier cities in the world, benchmarking against cities like Melbourne, Amsterdam, Frankfurt and Seattle. Moreover, the objective is to brand Chengdu towards Japan, Korea, North America and Europe. A focus on internationalization in Chengdu's city branding is related to the overall strategy of the city. Raising awareness is central:

In terms of Chengdu's international branding efforts, the goal is to increase awareness of Chengdu.

The objectives for Chengdu, as mentioned by the interviewees, also include creating economic development and a good image, to facilitate and boost the service industry, and to improve the city infrastructure. Tourism is also greatly focused on:

The objective of Chengdu is to build a truly international tourism destination.

The branding to international audiences following the 2008 earthquake focused on conveying and communicating that Chengdu still was a safe place. This strategy was to a large degree undertaken because the research that had been carried out internationally had shown that overseas target groups were concerned about visiting Chengdu due to safety reasons. A three-stage strategy was formulated:

We wanted to communicate that Chengdu still was safe, and also grateful for all the support the city received in connection to the earthquake; that Chengdu is a place full of opportunities; and a place where miracles can happen.

Investors were identified as an important target group:

International branding efforts targeted potential investors, emphasizing the fast growth of Chengdu and the safe and investment-friendly environment.

After the 2008 earthquake, and especially since 2010, the government in Chengdu has focused on branding Chengdu internationally as the "Real China". This has meant that Chengdu has kept the Chinese culture and some traditional characters of the city, but at the same time developed economically like the rest of China. Pandas have also played a key role in Chengdu's branding strategy: 
Since 2010 the focus in international branding has also been on the "Home of Panda", and the image of pandas has been used a lot in international branding.

The internet, web sites, social media and online branding are among the interviewees emphasized as crucial when targeting tourists and branding a city. Chengdu Culture and Tourism Group have conducted market research in collaboration with Pacific Asia Travel Association (PATA), showing that:

Especially in Western countries, 70 per cent of information collection related to tourism comes from the Internet. Apart from traditional, on-ground marketing activities, we are therefore putting a lot of efforts online.

Also other interviewees claim that there is a need to integrate online branding efforts with traditional marketing, to achieve successful city branding internationally.

\section{Method and expression}

The logo of Chengdu was created in 2011. The logo resembles four birds in a golden circle, and was inspired by the Golden Sunbird, which was excavated from the Jinsha ruins in 2001. Jinsha is an archaeological site near Chengdu that probably had its heyday around 1,000 years BC. It was not an obvious choice to pick the Golden Sunbird as the logo for Chengdu though:

At first the idea was to use Pandas and the Yinxing tree, which is famous in Chengdu. But then local residents were asked for advice online. And it turned out that to many people in Chengdu, the Golden Sunbird is a symbol that is inherited by ancestors, and a symbol that represents the city.

Apart from Chengdu's logo, an image frequently used in the branding of Chengdu is the panda, e.g. seen on Chengdu's Facebook page. The pandas are also often seen together with a person, quite often a non-Chinese person.

Other images and pictures used on web sites and in social media connected to Chengdu include: Chinese buildings and old traditional houses; skyscrapers as well as modern, extravagant and international buildings and architecture; a vibrant city full of life; lit up roads, buildings and streets. On web sites and in social media one can also find images of Chengdu international airport and Chengdu high tech zone. There are also many and varying pictures from Chengdu Fortune Global Forum, arranged in June 2013, including pictures of Chinese porcelain and spectacular, modern buildings.

Trees and water, flowers and fish, and the combination of city and nature are also present in the images. Maps of Chengdu and China, as well as scenic spots in and near Chengdu (like the Huanglong Valley) are also depicted in images. Pictures of Sichuan spicy food, the nine-grid hot pot, bars and restaurants are also present online. Cultural elements and local traditions, like Sichuan opera, the Dragon boat festival, and Kung $\mathrm{Fu}$ practice (e.g. between a Chinese and a non-Chinese person) are other images. The Chinese Nobel laureate in literature 2012, Mo Yan; Chengdu Bookworm Literary Festival; and China's first ever space lecture are other elements found online.

Chengdu's logo is sometimes accompanied by the tagline "Spice it up". Also pictures and images are occasionally supplemented with text, such as:

"Harmonious and tolerant", "Wise and honest", "An oasis of tranquillity", "Charms of the city", "The best tourism city of China", "China goes west", "A way into western China”, "The city to be" and "A new direction".

\section{Online city branding}

215 
JPMD

6,3

216

\section{Five illustrations}

Next, five illustrations are presented in order to shed light on how Chengdu has used and is using the internet and online branding in its international city branding efforts. Data from interviews along with examples of online city branding are presented in the following five sub-sections.

1. London Olympics 2012. For the 2012 Olympic Games in London, 50 taxis used around the Olympics venues were covered with pictures of Pandas and information about Chengdu. Chengdu city government sponsored the three-month program themed "Panda Cab Running for the Olympics". The Panda cabs were cruising around London from June 1 to August 31. Inside the taxis, brochures about Chengdu could be found, as well as bar codes that could be scanned using a smart phone, connecting the user to a web site in English, called "GoChengdu" which was launched in June 2012. On the GoChengdu web site it could for example be read that:

Chengdu always strives for raising the international community's awareness of endangered species conservation, promoting the harmony between man and nature, and further advocating the Olympic spirit of unity, friendship and peace.

The campaign also involved people dressed like Pandas, taking pictures with Olympic games visitors on London's main streets - pictures that then were posted on Chengdu's Facebook page.

2. Experience centres. A strategy used to market Chengdu as a tourist destination has been collaboration with partners in Chengdu's target markets, and for example the establishment of experience centres, e.g. in Taiwan, France, Korea, Japan and the USA. An interviewee explains:

The experience centres are serving as both physical and online platforms, including a store with information material about Chengdu, and promotional activities with the partners in each target market.

The experience centres imply access to local online and offline channels, including web sites and social media:

Through the partnership and the experience centres we are able to showcase Chengdu in various promotional activities, using local channels and websites. We work closely together, to promote the image of Chengdu.

The promotional activities revolve around themes, such as pandas and the Chengdu cuisine, and around culture and traditions, like the Lantern festival. Lantern festivals have been arranged in Japan, Singapore, and Poland.

During the Lantern festival, we bring together various traditional elements representing Chengdu, such as Sichuan food, ethnic singing and dancing groups, traditional craftsmanship, and cultural heritage like Sichuan embroidery.

On the lanterns are images of Chengdu, like pandas, the three kingdoms, and other pictures that represent the city.

3. Panda ambassadors. In 2010 the Chengdu Government (under the name "The City of Chengdu") recruited volunteers from all over the world, to become "Pambassadors" and visit Chengdu. An interviewee clarifies the process: 
A campaign was launched on Facebook, and over 60,000 people applied for the positions. Out of these, six applicants were selected, based on an online voting among netizens and based on the applicants' knowledge of Chengdu.
Online city branding

The winners won a one-month stay at the Chengdu Research Base of Giant Panda Breeding and free travel in Chengdu. In September 2012, a three-month campaign was again launched, searching for three "Pambassadors". A 60s long film on YouTube, was one element of the campaign. The film starts in a forest. The viewer sees an iPad and hears the sound of a forest. A black pawn is flickering through icons on the iPad screen, e.g. Twitter, YouTube, Google and Facebook, selecting the Facebook icon, getting to the "Chengdu Pambassador" Facebook page. The viewer sees a map of China, followed by an indication of where Chengdu is located. Images of Chengdu are then included in the film, showing the city life, the nature, along with music, and text like:

"Chengdu, China", "Explore pandas hometown, "Anticipate real pandas" smiles", "Experience the extraordinary journey", "Befriend the cutest creature on earth".

Next, the viewer sees a young foreign man trekking through the forest; at night by a tent; looking at photographs of pandas; seeing a panda glimmering in the night sky. He is then running through the forest; finally reaching the pandas and being amazed by the look of them. The viewer sees him playing with the pandas and taking pictures of them. Music is played, and in the end a speaker voice says:

Join our mission protecting pandas. Become the next Chengdu Pambassador, and win a chance to the Global panda conservation tour. The pandas are waiting for you!

The tree winners were presented in November 2012, e.g. on Facebook. In order to reach international audiences Chengdu Government used an international PR and advertising company in the campaign. The Panda ambassador project was moreover carried out in collaboration with the World Wildlife Fund (WWF).

4. Film productions. Films in different forms have been used to brand Chengdu internationally, using online and offline channels. In 2003, the famous director Zhang Yimou made a film in which Chengdu was promoted as a good place to eat and play. An interviewee says:

The film promoted the relaxing lifestyle of Chengdu, and included the sentence that became connected to Chengdu, "once you come, you never want to leave".

Another film, which has been showed on media outlets all over the world, e.g. on BBC, shows a panda touring around the city of Chengdu. The Chengdu Government has moreover invited the wildlife presenter and television producer Nigel Marven to visit Chengdu:

The outcome was a documentary film called "Marven's adventure in the Panda kingdom", showed on the Discovery channel in France and the UK, and communicated through online channels.

Marven was also involved as a Panda Ambassador and can be seen on YouTube in a short film shot in London. 
JPMD

6,3

218
5. Fortune Global Forum 2013. When data for the present study was gathered, Chengdu was preparing to arrange and be the host for the Fortune Global Forum 2013. An interviewee said:

A big opportunity ahead is that the Fortune Magazine has selected Chengdu as the host for the Fortune Global Forum, to be held in Chengdu in June 2013.

The Fortune Global Forum is an annual conference arranged by Fortune Magazine. The conference has been held since 1995, the first time in Singapore, and previously also in Hong Kong, Beijing and Shanghai. As stated in an interview:

The Forum will attract CEO's from "Fortune 500" firms as well as government officials from China and around the world.

In relation to the Global Fortune Forum, 2013, both the forum and Chengdu were promoted in various media and channels, e.g. CNN, BBC, and China CCTV. Information about the Global Fortune Forum, 2013 was also communicated via a Facebook page, and through other online channels such as web sites and on YouTube. An interviewee expressed hopes regarding the forum:

We really hope we can use the opportunity that the Fortune Global Forum represents, to market Chengdu abroad.

\section{Challenges in online city branding}

Branding Chengdu towards international audiences involves various challenges. One challenge is that Chengdu still is relatively unknown outside China. Another challenge in the international positioning, mentioned by some interviewees, is the great costs that international branding often implies, particularly as it needs to be combined with offline branding (which is often the case). In the case of Chengdu, there is moreover a need to engage PR and communication firms in order to assist with international online city branding, which also adds to the total expenses. The interactive, co-creative and dialogic character of online branding moreover implies that in order to be able to manage online city branding there is a need to communicate regularly with the target audiences. This naturally implies additional costs, especially if also the interaction is to be handled by an external party.

Another challenge is the level of knowledge and familiarity with online city branding. Some of the organisations and people engaged in city branding in Chengdu have limited experience with city branding practices in general, and online city branding in particular. Online branding is still largely perceived as more complex than traditional branding, and many still have limited familiarity with international media as well as city branding practices and online channels outside China. Commonly used social media in some of Chengdu's international target markets (like Facebook, YouTube and Twitter) cannot be accessed in China (at least not at the time when the present study was conducted and article written), but are common channels for branding on the international arena. Chengdu has faced this challenge by getting help and advice from PR and communication firms, some with offices and staff worldwide. Another way to get around this challenge has been to create experience centres and collaborations with local companies in the target markets.

Collaboration with PR and communication firms as well as local companies in the target markets have assisted Chengdu and people involved in international city 
branding to better understanding international target groups, and to learn more about online city branding in other countries and contexts. The five illustrations discussed in this article depict the collaboration that Chengdu engages in, and in addition to collaboration with PR and communication firms as well as local companies in target markets, also covers Chengdu's creation of connections with well-known organizations (e.g. WWF) and established events (Olympic Games and Global Fortune Forum, 2013).

Speaking more broadly, about the Chinese context and not only Chengdu, another challenge is related to the resistance among some city government officials towards the use of internet and online city branding. Reasons for this resistance can, according to some of the interviewees, be related to lack of knowledge of the benefits of using online city branding. Branding a city using the internet and interactive online channels moreover makes it harder to control the communication and the messages, which is of concern to some government officials. Nevertheless, there seem to be an increasing awareness of the importance to engage in dialogue and co-creation, for example seen in Chengdu when the new city logo was created and residents were asked for advice online.

\section{Discussion}

In terms of objectives and strategies, Chengdu's branding aimed at international audiences using online branding, has resemblance with Rowley's (2004a) proposed objectives in online branding, including a focus on raising awareness of Chengdu (a city which to many still is unknown), and increasing brand remembrance. Connections between Hays et al.'s (2012) proposed cycle for successful social media marketing, and the branding of Chengdu can also be found. As illustrated in the findings, efforts have been made in Chengdu to learn about user preferences, e.g. through market research and surveys about target audiences. Attracting users as well as engaging user interest and participation (also proposed in Hays, et al.'s cycle) has been seen, for example, in the illustration of the "Chengdu Pambassadors".

As illustrated in this study Chengdu is using multiple channels in their international city branding efforts. Online channels used are web sites, social media, online news media, films, video casts, etc. Online branding and the use of online channels is regarded as a complement to traditional branding, and the interviewees see a need to integrate digital media and traditional marketing to achieve successful city branding internationally. This is in line with Dobers and Hallin's (2009) suggestion that there is a need for a multi-channel strategy for branding and communication, including internet and digital marketing, in addition to more traditional channels. It is also in line with other scholars emphasis on the need to integrate marketing communications offline and online (Rowley, 2004b; Simmons, 2006).

In terms of expression of place brand identity and image, as discussed by Florek $e t a l$. (2006), it becomes clear that in the case of Chengdu, online city branding towards international audiences is influenced by certain imagery, or set of images. This imagery includes a combination of contrasting images, such as "modern" and "traditional", "vibrant city life" and "traditional culture", "city" and "nature", as well as "Chinese" and "foreigners" ("non Chinese"). Pandas and Chengdu's logo are also frequently used images. Both the notion of Chengdu as the "Real China", and Chengdu as the modern, high-tech and investment friendly context have been and are being promoted internationally.

\section{Online city branding}

219 
JPMD

6,3

\section{0}

A focus on tourism, scenic spots, and other elements that can attract potential tourists are also common imagery used.

A central aspect in the Chengdu case, and in the five illustrations presented in this study, is concerned with "endorsement" and thus making use of existing positive values of, e.g. a global city or a certain location (London), an international event (the Olympic Games), an organization (WWF), a prestigious forum (Global Fortune Forum), certain companies (Fortune 500 firms), esteemed wildlife presenter and television producer (Nigel Marven), etc. This method and way of expression, appears to tie into (and be aligned with) the objectives and strategy of Chengdu, as well as the imagery that the city is using in creating its city brand identity and image. For a city like Chengdu, which still is rather unknown in an international context, it can be seen as a feasible strategy to make use of and get connected with organizations, cities, etc. with already established values, associations and/or brands.

Challenges related to online city branding to international audience and the case of Chengdu include the great costs that international city branding implies; that "city brand managers" have limited experience with city branding and online city branding; a view of online branding as complex and difficult; that there is resistance among some government officials to accept interactive online branding channels; that there is a lack of access to international online channels (Facebook, YouTube, etc.); and that Chengdu so far is relatively unknown among international target groups.

An implication of the lack of access to international online media is that Chengdu has established collaborations with international communication and PR firms, and with local companies and organizations in the target markets. In the literature, for example, Hays et al. (2012), have maintained that the use of internet and online branding is a good way to achieve international city branding with limited resources. In the case of Chengdu however, the need for collaboration with PR firms, local organizations, etc. may result in rather extensive costs for online city branding towards international audiences. Associated costs are also related to the perceived need to combine online and offline branding (Rowley, 2004b) and Simmons (2006). The dialogic citizenship (Paganoni, 2012) as well as direct and strong user participation (Florek, 2011) that online branding and Web 2.0 contribute to, can be seen as increasing costs since human resources are needed to interact with the target groups. If knowledge and awareness of the target groups are limited, there may moreover be a need to employ consultants and/or firms to handle parts of the interaction.

Chengdu's collaboration with PR and communication firms and local companies in target markets can be regarded as an opportunity and also a solution to some of the challenges facing the city in its international online city branding. In collaboration with international, PR and communication firms, Chengdu has conducted market research, and learned about behaviours in target markets. The collaboration with consultants and firms has also implied access to expertise and knowledge on habits, behaviour, language and symbols in the target markets, and insights on how to brand Chengdu to international audiences. Related challenges can include that "city brand managers" in Chengdu cannot fully control the messages and images communicated, and thus need to trust its collaborators. Palmer (2004) has emphasized trust (and also leadership) as important issues in electronic marketing/online branding.

One can assume that Chengdu's engagement in online city branding, and its related need to collaborate with different actors, will have impact on Chengdu's 
branding strategy. One could also assume that, in the long-term perspective, the traditionally controlled and hierarchical way of conducting city branding in a Chinese setting (So and Shen, 2004; Xu and Yeh, 2005) will, by the influence from increased use of online channels and online city branding, bit by bit become increasingly distributed and interactive (Florek, 2011; Fouts, 2010). Effective leadership may nevertheless still obtain a central element in order to achieve the objectives of a group, and to reconcile the interests of different stakeholders, as pointed out by Palmer (2004).

\section{Conclusion}

This study was conducted with the background that limited studies have dealt with how cities use online branding in their city branding, and on the basis that there is a need for case studies looking at how cities use information and communication technologies in their branding work (Dobers and Hallin, 2009). The study was also conducted on the basis that limited studies on online city branding have included both web sites and social media in their scope; that few studies focus on how cities combine online and offline branding efforts; and that limited studies focus on the challenges posed in online city branding. Yet, online city branding is something that cities increasingly engage in, and is as such important to understand and learn more about.

The present study has offered insight regarding how Chengdu has been positioned internationally using online city branding. The study has involved a focus on web sites and social media, as well as offline and online branding (with a focus on online branding). The focus has moreover been on "Objectives and strategies", "Method and expression", and "Challenges in online city branding". Some of the challenges presented in this study, e.g. that Chengdu is relatively unknown; that online city branding is rather expensive; and that there is a lack of awareness and knowledge and experience of international online media. Endorsement (and thus using a well established brand, e.g. WWF, Olympic Games, Global Fortune Forum), as well as collaboration with international, PR and communication firms as well as partners in key markets, can be regarded as a response (and in part a solution) to these challenges.

Hays et al. (2012), pointed out that the use of social media among DMOs I still largely experimental and that strategies vary greatly. In the extension, one can assume that also online city branding still is experimental, and that varying strategies are used worldwide. The generalizability of the present study can consequently be questioned, and in Stake's (1995) view, the case study method is involved with particularization, not generalization. Nevertheless, it is still possible to see implications of the present study, for research and practice.

This article and study has contributed to the literature on online city branding by adding a single-case study and an example showing how a large metropolitan city like the Chinese city of Chengdu has been positioned internationally using online city branding. To some degree the study has confirmed previous studies and literature (e.g. the need for a combination of online and offline branding), contradicted previous literature (e.g. online city branding is not necessarily an inexpensive branding strategy), and offered some new insights (e.g. highlighted challenges in online city branding, and described some proposed responses and solutions to these challenges).

The present study offers insights to practitioners on how online city branding and international positioning is carried out in a Chinese context and in the city of Chengdu. Insight from the present study is offered regarding some of the challenges facing a city

\section{Online city branding}

221 
JPMD

6,3

222 that is involved in online city branding to international audiences. The case of Chengdu moreover highlights the importance of collaboration and "endorsement" as well as learning about user preferences, target groups and target markets. The importance of carefully selecting a few (not too many) target audiences to focus on is also a valuable lesson from the Chengdu case. Being a Chinese city that is relatively unknown to an international audience, it can be assumed that, for example, "city branding managers" in cities with a similar context and situation to that of Chengdu, can especially benefit from the present study. Implications should however be applicable also to practitioners in cities with other characteristics than those of Chengdu.

Further research could take its starting point on the same basis that this article did, namely studying the combined use of online and offline city branding, including a focus on different internet tools (e.g. both web sites and social media), and further exploring challenges in online city branding to international audiences. More research could also explore what shape endorsement and collaboration can take, and how it can be handled efficiently. The role of trust and leadership in relation to online city branding as well as endorsement and collaboration are other interesting topics to study further. Additional research could also focus on city brand management and co-creation of city brand identity, values and meaning among various audiences, through online city branding. Moreover, the possible challenges caused by the interactive, co-creating dimension of online channels, versus a more hierarchical, sender-oriented approach to branding, still remains to be further understood and elaborated on in the literature. Lastly, it would be interesting to explore what the next step after Web 2.0 has to offer in relation to online city branding and international positioning.

\section{References}

Alam, I. (2005), "Fieldwork and data collection in qualitative marketing research", Qualitative Marketing Research: An International Journal, Vol. 8 No. 1, pp. 97-112.

Anholt, S. (2002), "Nation branding: a continuing theme", Journal of Brand Management, Vol. 10, pp. 59-60.

Anholt, S. (2005), "Some important distinctions in place branding", Place Branding and Public Diplomacy, Vol. 1 No. 2, pp. 116-121.

Balakrishnan, M. (2009), "Strategic branding of destinations: a framework", European Journal of Marketing, Vol. 43 Nos 5/6, pp. 611-629.

Balmer, J.M.T. and Greyser, S.A. (2006), "Corporate marketing - integrating corporate identity, corporate branding, corporate communications, corporate image and corporate reputation”, European Journal of Marketing, Vol. 40 Nos 7/8, pp. 730-741.

Bell, J. (1999), Doing Your Research Project, 3rd ed., Open University Press, Buckingham.

Buhalis, D. and Spada, A. (2000), "Destination management systems: criteria for success - an exploratory research”, Information Technology \& Tourism, Vol. 3 No. 1, pp. 41-58.

Chaffey, D., Ellis-Chadwick, F., Mayer, R. and Johnston, K.J. (2009), Internet Marketing: Strategy, Implementation and Practice, 4th ed., Pearson Education, Harlow.

Choi, S., Lehto, X. and Morrison, A. (2007), "Destination image representation on the web: content analysis of Macau travel related websites", Tourism Management, Vol. 28, pp. 118-129.

Christodoulides, G. (2009), "Branding in the post-internet era”, Marketing Theory, Vol. 9 No. 1, pp. 141-144. 
Da Silva, R. and Syed Alwi, S. (2008), "Online brand attributes and online corporate brand images”, European Journal of Marketing, Vol. 42 Nos 9/10, pp. 1039-1058.

Dinnie, K. (2011), City Branding: Theories and Cases, Palgrave Macmillan, New York, NY.

Dobers, P. and Hallin, A. (2009), "The use of internet in building the brand of Stockholm: the capital of Scandinavia", Information Communication Technologies and City Marketing: Digital Opportunities for Cities Around The World, Information Science Reference, London, pp. 265-294.

Dubois, A. and Gadde, L.-E. (2002), "Systematic combining: an abductive approach to case research", Journal of Business Research, Vol. 55, pp. 553-560.

Eckhardt, G. and Dholakia, N. (2013), "Addressing the mega imbalance: interpretive exploration of Asia”, Qualitative Market Research: An International Journal, Vol. 16 No. 1, pp. 4-11.

Florek, M. (2011), “Online city branding”, in Dinnie, K. (Ed.), City Branding: Theory and Cases, Palgrave Macmillan, New York, NY, pp. 82-90.

Florek, M., Insch, A. and Gnoth, J. (2006), "City council websites as a means of place brand identity communication”, Place Branding and Public Diplomacy, Vol. 2, pp. 276-296.

Fouts, J. (2010), "Social media and immersive worlds: why international place branding doesn't get weekends off", in Go, F. and Govers, R. (Eds), International Place Branding Yearbook 2010: Place Branding in the New Age of Innovation, Palgrave Macmillan, New York, NY, pp. $113-120$.

Gertner, R., Berger, K. and Gertner, D. (2007), "Country-dot-com: marketing and branding destinations online", Journal of Travel \& Tourism Marketing, Vol. 21 Nos 2/3, pp. 105-116.

Go, F. and Govers, R. (2010), International Place Branding Yearbook 2010: Place Branding in the New Age of Innovation, Palgrave Macmillan, New York, NY, pp. 113-120.

Hanna, S. and Rowley, J. (2011), "Towards a strategic place brand-management model", Journal of Marketing Management, Vol. 27 Nos 5/6, pp. 458-476.

Hatch, M. and Schultz, M. (2009), "Of bricks and brands: from corporate to enterprise branding”, Organizational Dynamics, Vol. 38 No. 2, pp. 117-130.

Hays, S., Page, S.J. and Buhalis, D. (2012), "Social media as a destination marketing tool: its use by national tourism organisations", Current Issues in Tourism, pp. 1-29.

Heimer, M. and Thøgersen, S. (2011), Doing Fieldwork in China, NIAS Press, Copenhagen.

Hospers, G.-J. (2010), "Making sense of place: from cold to warm city marketing”, Journal of Place Management and Development, Vol. 3 No. 3, pp. 182-193.

Jacques, M. (2009), When China Rules the World: The Rise of the Middle Kingdom and the End of the Western World, Penguin Books, London.

Kaplan, A. and Haenlein, M. (2010), "Users of the world, unite! The challenges and opportunities of social media”, Business Horizons, Vol. 53, pp. 59-68.

Kavaratzis, M. (2004), "From city marketing to city branding: towards a theoretical framework for developing city brands", Place Branding, Vol. 1 No. 1, pp. 58-73.

Kavaratzis, M. (2005), "Place branding: a review of trends and conceptual models", The Marketing Review, Vol. 5, pp. 329-342.

Kavaratzis, M. (2007), "City marketing: the past, the present and some unresolved issues", Geography Compass, Vol. 1 No. 3, pp. 695-712.

Kavaratzis, M. (2009), “Cities and their brands: lessons from corporate branding”, Place Branding and Public Diplomacy, Vol. 5 No. 1, pp. 26-37. 
JPMD

6,3
Kotler, P. and Gertner, D. (2002), "Country as brand, product, and beyond: a place marketing and brand management perspective", The Journal of Brand Management, Vol. 9 No. 4, pp. 249-261.

Law, R., Qi, S. and Buhalis, D. (2010), "Progress in tourism research: a review of website evaluation in tourism research", Tourism Management, Vol. 31, pp. 297-313.

Lever, W. and Turok, I. (1999), "Competitive cities: introduction to the review", Urban Studies, Vol. 36 Nos 5/6, pp. 791-793.

Lucarelli, A. and Berg, P.-O. (2011), "City branding - a state of the art review of the research domain”, Journal of Place Management and Development, Vol. 4 No. 1, pp. 9-27.

Neuman, W.L. (2007), "Analysis of qualitative data”, Social Research Methods: Qualitative and Quantitative Approaches, Pearson Education, Upper Saddle River, NJ, pp. 417-443.

O’Brien, K.J. (2011), "Discovery, research (re)design, and theory building”, in Heimer, M. and Thøgersen, S. (Eds), Doing Fieldwork in China, NIAS Press, Copenhagen, pp. 27-41.

Opoku, R. and Hinson, R. (2006), "Online brand personalities: an exploratory analysis of selected African countries”, Place Branding and Public Diplomacy, Vol. 2 No. 2, pp. 118-129.

Paganoni, M.C. (2012), "City branding and social inclusion in the Glocal city", Mobilities, Vol. 7 No. 1, pp. 13-31.

Palmer, A. (2004), "The internet challenge for destination marketing organizations", in Pritchard, M. and Pride, R. (Eds), Destination Branding: Creating the Unique Destination Proposition, Elsevier Butterworth-Heinemann, Oxford, pp. 128-140.

Polsa, P. (2013), "Crystallization and research in Asia”, Qualitative Market Research: An International Journal, Vol. 16 No. 1, pp. 76-93.

Rainisto, S.K. (2003), "Success factors of place marketing: a study of place marketing practices in Northern Europe and the United States", doctoral dissertation, Helsinki University of Technology, Institute of Strategy and International Business, Espoo.

Rowley, J. (2004a), “Online branding”, Online Information Review, Vol. 28 No. 2, pp. 131-138.

Rowley, J. (2004b), “Online branding: the case of McDonald's”, British Food Journal, Vol. 106 No. 3, pp. 228-237.

Sassen, S. (2004), "Local actors in global politics", Current Sociology, Vol. 52 No. 4, pp. 649-670.

Silverman, D. (1993), Interpreting Qualitative Data: Methods for Analyzing Talk, Text and Interaction, Sage, London.

Silverman, D. (2005), Doing Qualitative Research, 2nd ed., Sage, London.

Simmons, G. (2006), “i-Branding': developing the internet as a branding tool”, Marketing Intelligence \& Planning, Vol. 25 No. 6, pp. 544-562.

So, M.-S. and Shen, J. (2004), "Measuring urban competitiveness in China", Asian Geographer, Vol. 23 Nos 1/2, pp. 71-91.

Stake, R. (1995), The Art of Case Study Research, Sage, Thousand Oaks, CA.

Thevenot, G. (2007), "Blogging as a social media", Tourism and Hospitality Research, Vol. 7 Nos 3/4, pp. 282-289.

Thomas, D. (2006), "A general inductive approach for analyzing qualitative evaluation data", American Journal of Evaluation, Vol. 27 No. 2, pp. 237-246.

Trueman, M., Cornelius, N. and Wallace, J. (2012), "Building brand value online: exploring relationships between company and city brands", European Journal of Marketing, Vol. 46 No. 7, pp. 1013-1031. 
Ulaga, W., Sharma, A. and Krishnan, R. (2002), "Plant location and place marketing: understanding the process from the business customer's perspective", Industrial Marketing Management, Vol. 31 No. 5, pp. 393-401.

Urban, G. (2004), Digital Marketing Strategy: Text and Cases, Pearson Education, Upper Saddle River, NJ.

Varadarajan, R. and Yadav, M. (2009), "Marketing strategy in an internet-enabled environment: a retrospective on the first ten years of JIM and a prospective on the next ten years", Journal of Interactive Marketing, Vol. 23 No. 1, pp. 11-22.

Wai, A.W.T. (2006), "Place promotion and iconography in Shanghai's Xintiandi", Habitat International, Vol. 30, pp. 245-260.

Wang, L. and Zheng, J. (2010), "China and the changing landscape of the world economy", Journal of Chinese Economic and Business Studies, Vol. 8 No. 3, pp. 203-214.

Warnaby, G. (2009), "Towards a service-dominant place marketing logic", Marketing Theory, Vol. 9 No. 4, pp. 403-423.

Wu, F. (2000), "Place promotion in Shanghai, PRC”, Cities, Vol. 17 No. 5, pp. 349-361.

Wu, F. (2003), "Globalization, place promotion and urban development in Shanghai", Journal of Urban Affairs, Vol. 25 No. 1, pp. 55-78.

Xiang, Z. and Gretzel, U. (2010), "Role of social media in online travel information search", Tourism Management, Vol. 31, pp. 179-188.

$\mathrm{Xu}, \mathrm{J}$. and Yeh, A. (2005), "City repositioning and competitiveness building in regional development: new development strategies in Guangzhou", International Journal of Urban and Regional Research, Vol. 29, pp. 283-308.

Yan, J. (2011), "Social media in branding: fulfilling a need", Journal of Brand Management, Vol. 18, pp. 688-696.

Yin, R. (2003), Case Study Research: Design and Methods, 3rd ed., Sage, Thousand Oaks, CA.

Zenker, S. (2009), "Who's your target? The creative class as a target group for place branding", Journal of Place Management and Development, Vol. 2 No. 1, pp. 23-32.

Zenker, S. and Martin, N. (2011), "Measuring success in place marketing and branding", Place Branding and Public Diplomacy, Vol. 7 No. 1, pp. 32-41.

Zhang, L. and Zhao, S.X. (2009), "City branding and the Olympic effect: a case study of Beijing”, Cities, Vol. 26, pp. 245-254.

\section{YouTube clips referred to in the article}

Global Fortune Forum (2013), "Fortune global forum 2013", available at: www.youtube.com/ watch?v=GKdw7hvwVes (accessed 8 February 2013).

Nigel Marven in London (2012), "Nigel Marven loves pandas, how about you?", available at: www.youtube.com/watch?v=-AByGeEPDCI (accessed 27 October 2012).

60-second long film on YouTube (2012), Chengdu Pambassador 2012 - Official Invitation 60s, available at: www.youtube.com/watch?v=eDJW6Do8IEo (accessed 25 April 2013).

\section{Additional online material}

CNN International (2012a), available at: www.cnngo.com/shanghai/life/panda-power-chengduhires-london-black-cabs-drive-tourism-416171 (accessed 5 October 2012).

CNN International (2012b), "Cutest job in the world? Chengdu seeks panda ambassadors", available at: www.cnngo.com/shanghai/life/cutest-job-world-chengdu-seek-pandaambassadors-532161 (accessed 5 October 2012). 
JPMD

6,3

226

Discovery Press Web (2012), available at: http://press.discovery.com/emea/apl/programs/pandaadventure-nigel-marven/ (accessed 5 October 2012).

Report about the earthquake in Sichuan 6 months after it happened (2008), "Sichuan's earthquake, six months later", available at: www.boston.com/bigpicture/2008/11/ sichuans\&lowbar;earthquake\&lowbar;six\&lowbar;months.html (accessed 7 October 2012).

WWF Global (2012), available at: http://wwf.panda.org/what\&lowbar;we\&lowbar;do/footprint/ cities/urban\&lowbar;solutions/themes/resilience/?204394/Chengdu (accessed 13 October 2012).

\section{About the author}

Emma Björner is a $\mathrm{PhD}$ candidate in Marketing at Stockholm University School of Business (SUSB), studying the strategic branding and global positioning of Chinese mega-cities. Emma started her PhD in September 2011. Prior to that she worked as a Research Assistant at SUSB in Prof. Berg's team, within the research programme "Branding Metropolitan Place in Global Space". Emma has a Master degree in marketing and management and a Bachelor degree in media and communication. She has lived in China for two and half years, in Guangzhou (2006-2008) and in Shanghai (2010). Emma Björner can be contacted at: ebj@fek.su.se 